\title{
Urban air pollution and forests
}

\author{
A. Matzarakis, H. Mayer, P. Sczepanski \\ Meteorological Institute, University of Freiburg, D-79085 Freiburg, \\ Germany \\ EMail:matzarak@uni-freiburg.de
}

\begin{abstract}
Close to city forests have distinct recreational purposes, according to air pollution conditions. There are influenced by internal and external factors. The differences in air pollution structure between two cities and two forests which are close to the cities in Southwest Germany were investigated. The results are based on data supplied by official stations for the monitoring of air quality, in this case for the pollutants $\mathrm{NO}, \mathrm{NO}_{2}$ and $\mathrm{O}_{3}$ in the period 1992 through 1996. The results for both weekdays and weekends, presented as average diurnal cycles of the analysed air pollutants, reveal that concentrations of $\mathrm{NO}$ and $\mathrm{NO}_{2}$ were much higher in urban areas. Levels of concentration of $\mathrm{O}_{3}$, however, were higher in the close to city forests. The differences in air quality depend on the specific location of land use investigated as well as on the situation regarding pollutant emission within the cities.
\end{abstract}

\section{Introduction}

Forests can generally be regarded as having three functions: (1) productive, (2) protective and (3) recreational. In the case of forests which are close to cities, the latter purpose is most important. The sociological basis for this is evident: the proximity of city-dwellers and the consequent frequency of visitors (for details see Karameris [1]). Human-biometeorological factors (Mayer and Höppe [2]) also play a role - „good air“ being one example. These forests are particularly valuable from the point of view of urban climate, in that they are areas from which fresh and cold air can flow into ur- 
ban spaces. This reduces thermal stress in the summer season as well as easing the intensity of air pollution throughout the year (Matzarakis and Mayer [3]).

There is a high level of qualitative knowledge concerning air quality within forests, but quantitative results for the behaviour of the air pollutants within forests are few. This article therefore focuses on the differences among selected air pollutants between cities and close to city forests.

\section{Data}

The data investigated for air pollution was collected from two sets of official stations for the monitoring of air quality monitoring, situated in Southwest Germany. One set (hereafter abbreviated by SW) consisted of the two urban stations „Stuttgart-Mitte“ (235 m asl) and „Stuttgart-Bad Cannstatt“ (235 $\mathrm{m} \mathrm{asl}$ ) and also the forest station „Welzheimer Wald“ (500 $\mathrm{m}$ asl), situated about $40 \mathrm{~km}$ northeast of Stuttgart. A comparatively high traffic density is characteristic of „Stuttgart-Mitte“ and „Stuttgart-Bad Cannstatt“. The city of Stuttgart, which lies in a basin opening out to the east, has about 600.000 residents. The station „Stuttgart-Mitte“ is almost directly in the centre of Stuttgart, whereas „Stuttgart-Bad Cannstatt“ is located towards the eastern side.

The second set (hereafter abbreviated by FS) included air quality monitoring stations in the southern Upper Rhine valley about $100 \mathrm{~km}$ south west of Stuttgart: the two urban stations „Freiburg-Mitte“ (240 m asl) and „Freiburg-Nord“ (245 m asl) and the forest station „Schwarzwald-Süd“ (920 $\mathrm{m}$ asl). The city of Freiburg has about 200.000 residents and is situated in the eastern part of the southern Upper Rhine valley. The traffic density which affects the stations here is of course lower than is the case in Stuttgart. The forest station „Schwarzwald-Süd“ (about $25 \mathrm{~km}$ south of Freiburg) lies at the top of the hill „Kälbelescheuer“, which is on the western edge of the Black Forest.

The detailed analysis of data for the period 1992 through 1996, which was undertaken by Sczepanski [4], related to the air pollutants $\mathrm{NO}, \mathrm{NO}_{2}$ and $\mathrm{O}_{3}$. The sampling of these took place at $3 \mathrm{~m}$ above ground level. In studying the results one may note that besides volatile organic compounds, nitrogen oxides are important precursor species for the formation of ozone $\left(\mathrm{O}_{3}\right)$, and that NO is mostly emitted by motor-traffic.

\section{Results}

\subsection{Nitrogen oxide NO}


The high emission of NO in the areas surrounding the urban stations (Mayer et al. [5]) entails higher values in the average diurnal cycles for this pollutant (Figures 1 and 2). The level of NO was always higher at the urban stations in Stuttgart than at those in Freiburg, due to the higher traffic density in Stuttgart. The average concentrations of $\mathrm{NO}$ at both forest stations almost attained the analysing precision, with values at „Schwarzwald-Süd“ being somewhat higher.

---- Stuttgart-Mitte $\cdots \cdots \cdot$ Stuttgart-Bad Cannstatt - Welzheimer Wald

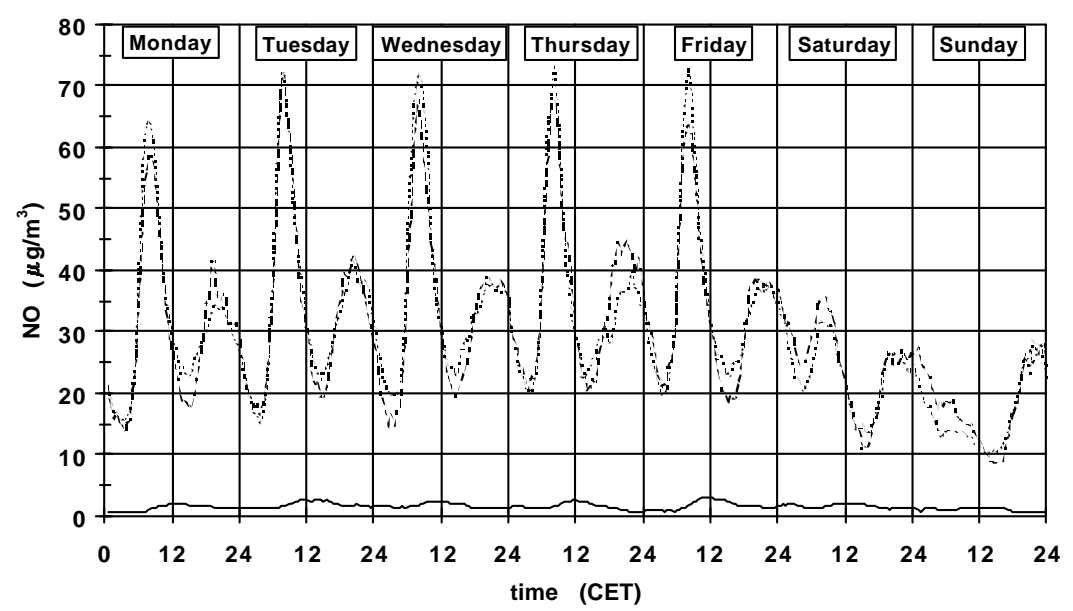

Figure 1: Average concentrations of NO at the two urban air quality monitoring stations „Stuttgart-Mitte“ and „Stuttgart-Bad Cannstatt“ and at the nearby forest air quality monitoring station ,Welzheimer Wald“ for the period 1992 through 1996. 


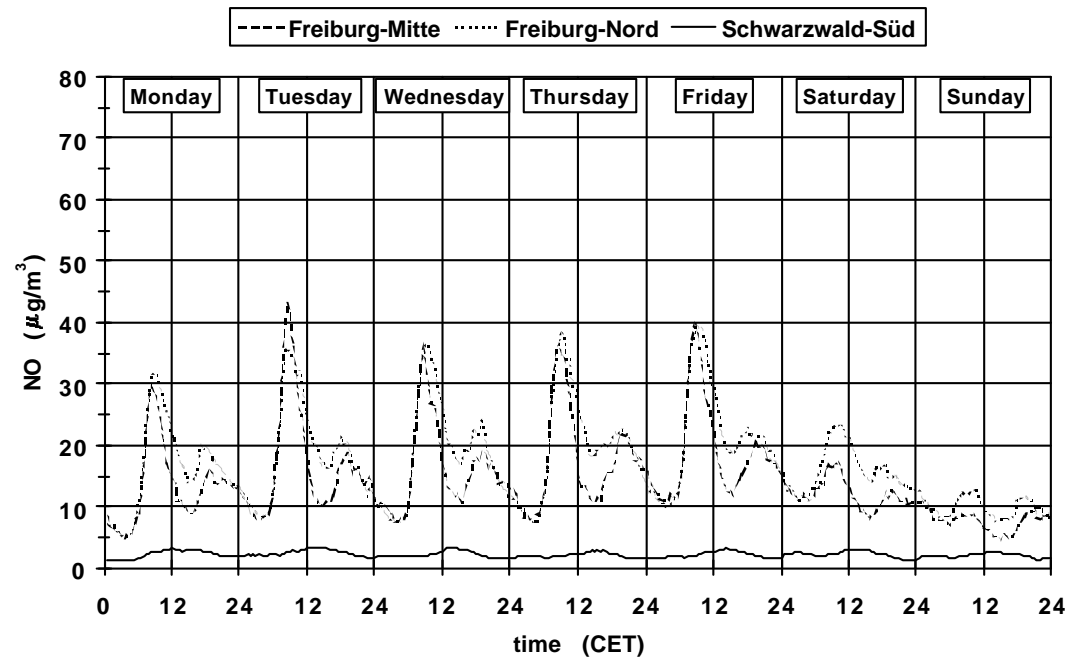

Figure 2: Average concentrations of NO at the two urban air quality monitoring stations „Freiburg-Mitte“ and „Freiburg-Nord“ and at the nearby forest air quality monitoring station „Schwarzwald-Süd“ for the period 1992 through 1996.

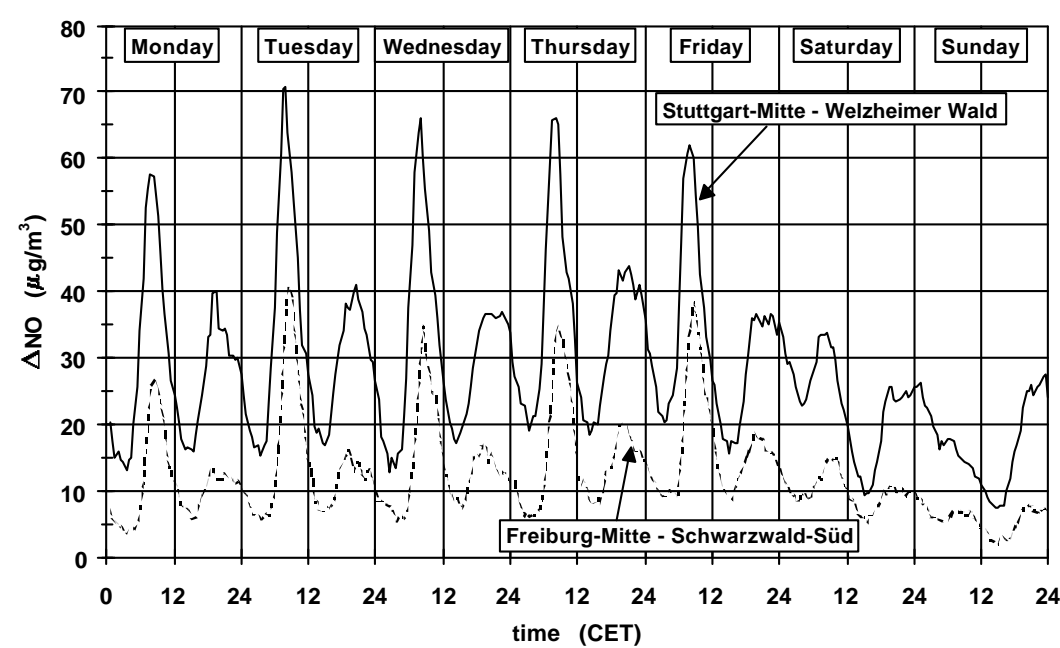

Figure 3: Differences between the average concentrations of NO at the urban air quality monitoring station ,Stuttgart-Mitte“ and the forest air quality monitoring station ,Welzheimer Wald“, also at the urban air quality monitoring station „Freiburg-Mitte“ and the for- 
est air quality monitoring station „Schwarzwald-Süd“, for the period 1992 through 1996.

Due to the change in behaviour of motor traffic at weekends compared to during the week, average concentrations of NO decreased on weekend. Average concentrations of NO at the forest stations, however, were not influenced by the weekday to weekend variation in NO emissions (Mayer and Haustein [6], Hau-stein and Mayer [7]).

The higher concentrations of NO at „Stuttgart-Mitte“ in comparison to „Frei-burg-Mitte“ caused higher values of the differences of this pollutant between one urban and the forest station at SW than at FS (Figure 3). In analogy to the diurnal courses of the average concentrations of NO at the urban stations, these NO differences had lower peak values for Saturday and Sunday (weekend) than for weekdays.

\subsection{Nitrogen dioxide $\mathrm{NO}_{2}$}

$\mathrm{NO}_{2}$ is not emitted directly by motor-traffic but is formed mostly by chemical reactions. The average concentrations of $\mathrm{NO}_{2}$ for $\mathrm{SW}$ (Figure 4) and FS (Figure 5) were higher at the urban stations than at the forest stations. The diurnal cycles of $\mathrm{NO}_{2}$ at the urban $\mathrm{SW}$ stations were pleasantly compatible, whereas at FS the urban station „Freiburg-Nord“ always had higher average values, with peak dif-ferences occurring shortly after midday.

----Stuttgart-Mitte $\cdots \cdots \cdot$ Stuttgart-Bad Cannstatt - Welzheimer Wald

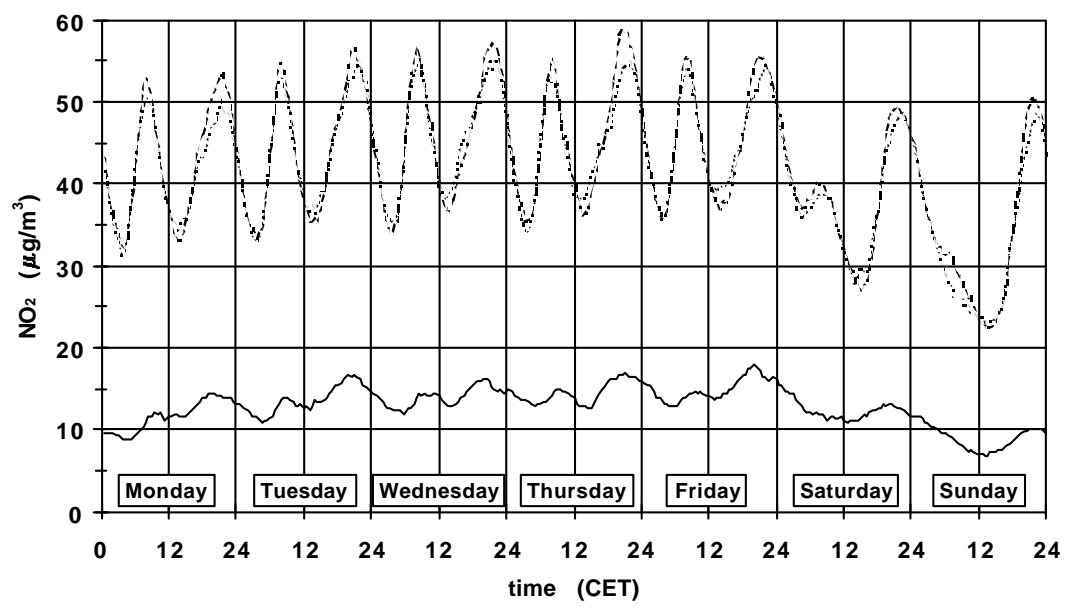


Figure 4: Average concentrations of $\mathrm{NO}_{2}$ at the two urban air quality monitoring stations ,Stuttgart-Mitte“ and „Stuttgart-Bad Cannstatt“ and at the nearby forest air quality monitoring station „Welzheimer Wald" for the period 1992 through 1996.

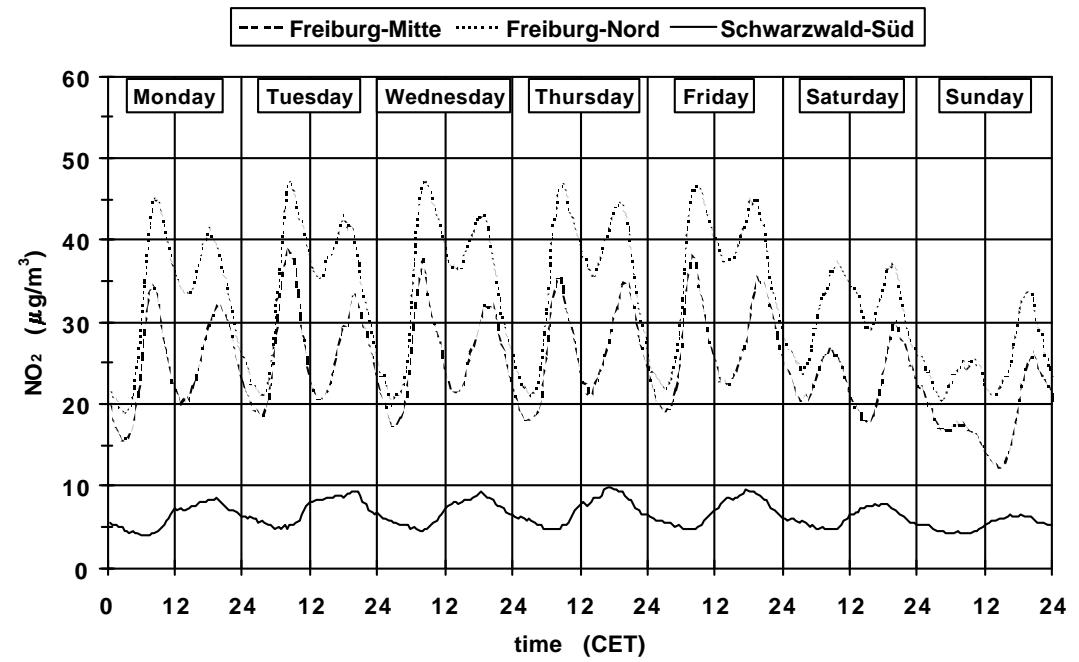

Figure 5: Average concentrations of $\mathrm{NO}_{2}$ at the two urban air quality monitoring stations „Freiburg-Mitte“ and „Freiburg-Nord“ and at the nearby forest air quality monitoring station „Schwarzwald-Süd“ for the period 1992 through 1996. 


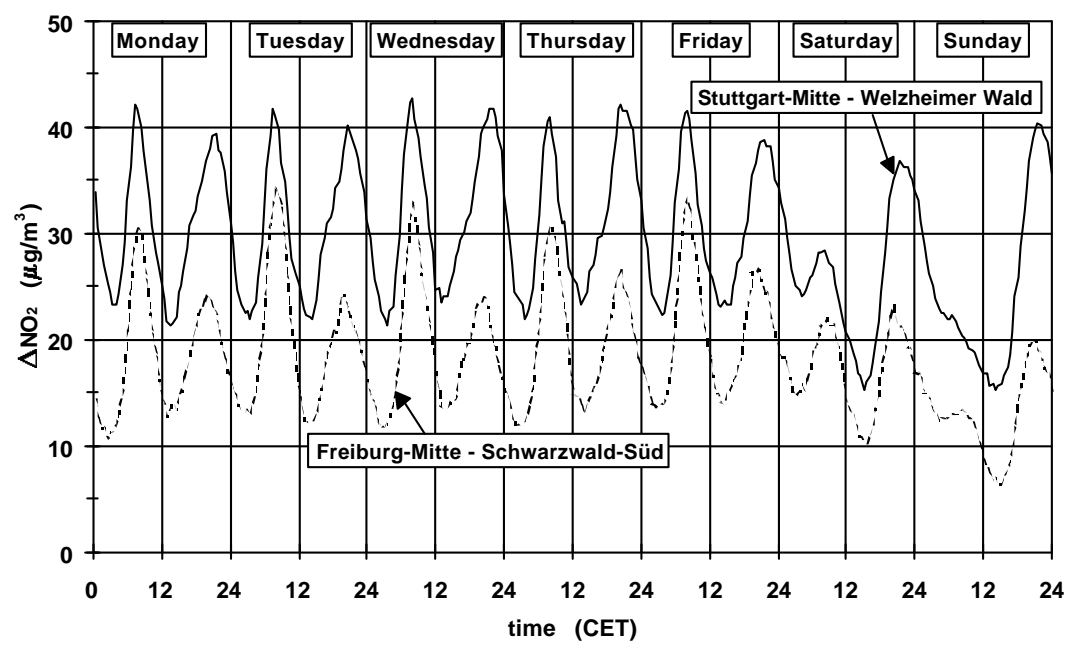

Figure 6: Differences between the average concentrations of $\mathrm{NO}_{2}$ at the urban air quality monitoring station ,Stuttgart-Mitte“ and the forest air qual-ity monitoring station „Welzheimer Wald“, also at the urban air quality monitoring station „Freiburg-Mitte“ and the forest air quality mon-itoring station „Schwarzwald-Süd“, for the period 1992 through 1996.

These results demonstrate the variability of air pollutants within cities according to the different arrangement of urban structures. Average concentrations of $\mathrm{NO}_{2}$ were always higher at ,Schwarzwald-Süd“ in comparison to those of the other forest station „Welzheimer Wald“. The pattern of average diurnal courses of concentrations of $\mathrm{NO}_{2}$ is similar to that which occurs in other investigations (e.g. Mayer et al. [5]), and reveals the differences between weekday and weekend activity.

Results in Figure 6 indicate that the differences in average concentrations of $\mathrm{NO}_{2}$ between an urban station and a nearby forest station were higher for SW than FS. The main differences between SW and FS on weekdays occurred in the evening. This is because at „Freiburg-Mitte“ the second sets of peak values of $\mathrm{NO}_{2}$ were lower than first (morning) peak values. At „Stuttgart-Mitte“, however, there were virtually no differences between the two.

\subsection{Ozone $\mathrm{O}_{3}$}


The diurnal courses of average concentrations of $\mathrm{O}_{3}$ were on a higher level at FS than at SW with values at the forest stations being significant higher (Figures 7 and 8).

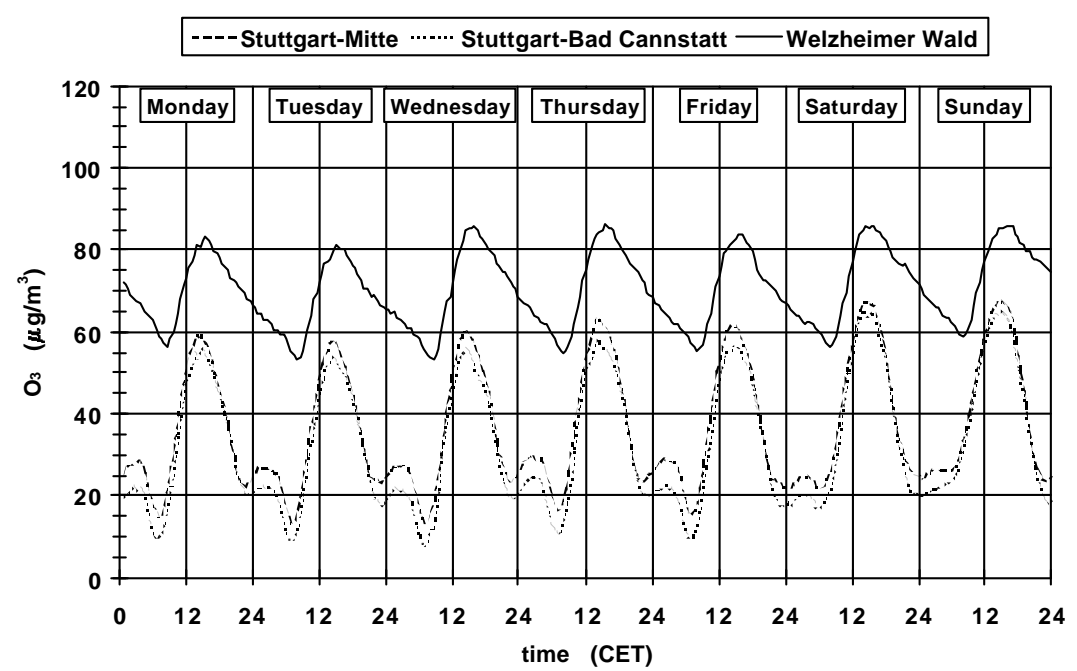

Figure 7: Average concentrations of $\mathrm{O}_{3}$ at the two urban air quality monitoring stations „Stuttgart-Mitte“ and „Stuttgart-Bad Cannstatt“ and at the nearby forest air quality monitoring station ,Welzheimer Wald" for the period 1992 through 1996.

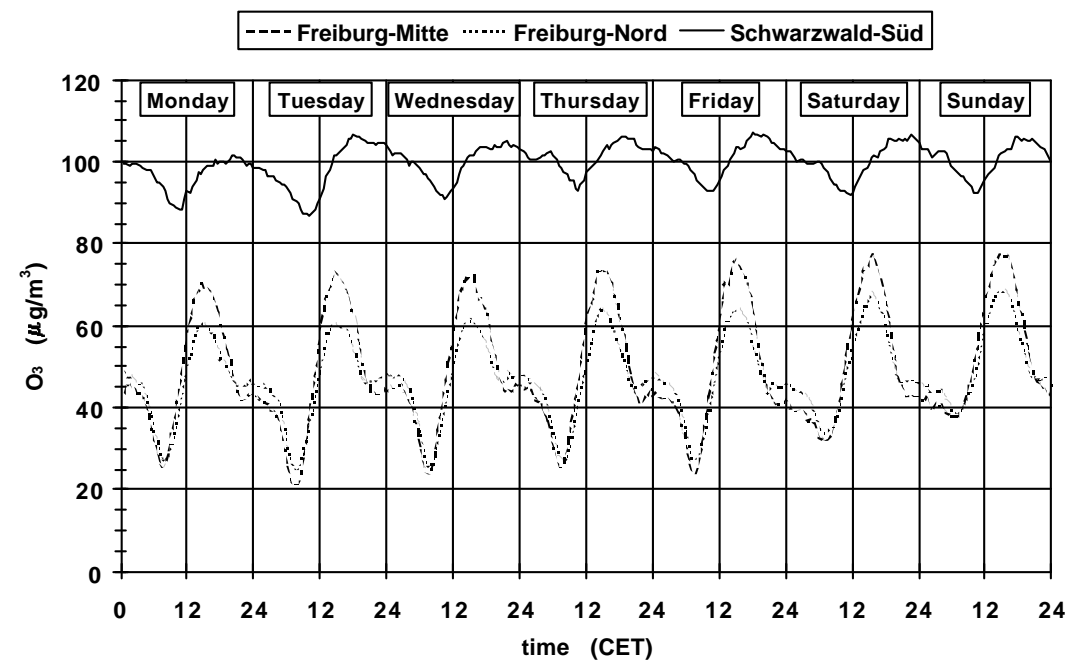


Figure 8: Average concentrations of $\mathrm{O}_{3}$ at the two urban air quality monitoring stations „Freiburg-Mitte“ and „Freiburg-Nord“ and at the nearby forest air quality monitoring station „Schwarzwald-Süd“ for the period 1992 through 1996.

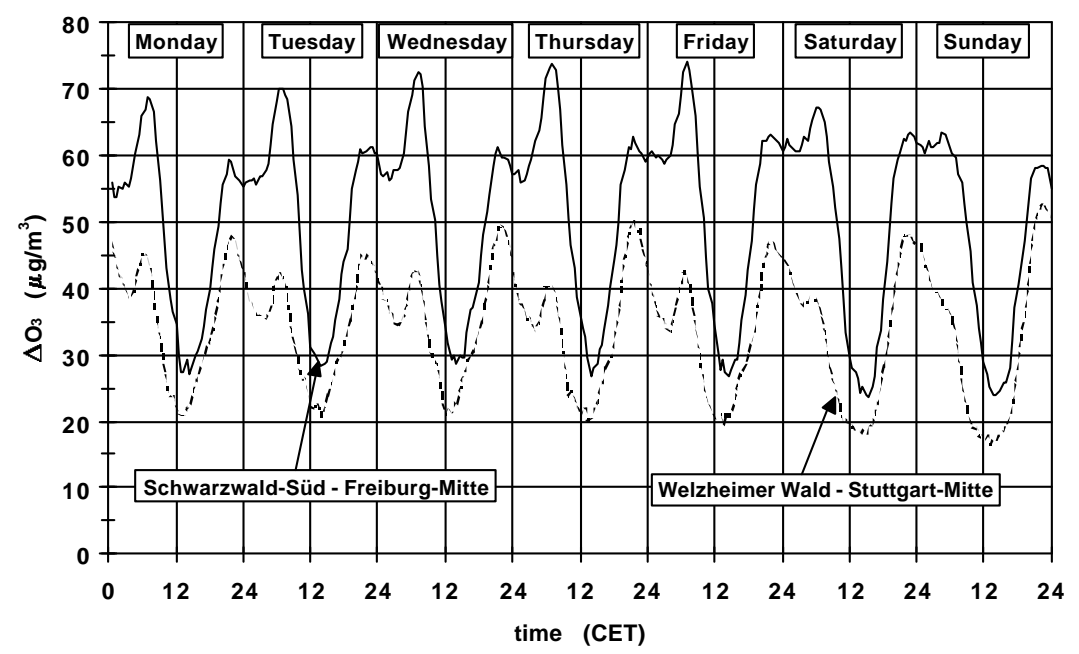

Figure 9: Differences between the average concentrations of $\mathrm{O}_{3}$ at the forest air quality monitoring station „Welzheimer Wald“ and the urban air qual-ity monitoring station „Stuttgart-Mitte“, also at the forest air quality monitoring station „Schwarzwald-Süd“ and the urban air quality mon-itoring station „Freiburg-Mitte“, for the period 1992 through 1996.

The diurnal courses of $\mathrm{O}_{3}$ at „Schwarzwald-Süd“ were at the highest level and showed the smallest amplitudes per day of all stations investigated. This was caused by the specific location of „Schwarzwald-Süd“ in $950 \mathrm{~m}$ asl.

The greatest differences in average concentrations of $\mathrm{O}_{3}$ between the forest station and the urban stations occurred in the morning (Figure 9) when the diurnal courses of average concentrations of $\mathrm{O}_{3}$ at the urban stations showed their lowest values. The lowest values of $\mathrm{O}_{3}$ at the forest stations were always recorded some hours later.

\section{Average values of $\mathrm{NO}, \mathrm{NO}_{2}$ and $\mathrm{O}_{3}$}

Table 1 contains average values of $\mathrm{NO}, \mathrm{NO}_{2}$ and $\mathrm{O}_{3}$ for the period 1992 through 1996, for SW and FS. These values summarise the results obtained 
for the differences between urban and forest air pollution, by the diurnal courses of average concentration levels of the investigated air pollutants. Due to general temporal trends in air pollutant behaviour (Mayer and Schmidt [8]), the differences between the air pollutant values at urban and forest stations are disclosed through percentage. Lower differences are identified between the city stations, indicating the variability of near surface air pollutants caused by different urban structures. The differences between urban and forest stations are higher. The extend to which differences occur depends on several factors. The specific location of the air quality monitoring station, the intensity of motor-traffic and background level of air pollution are among the most important of these.

Table 1: Average concentrations of $\mathrm{NO}, \mathrm{NO}_{2}$ and $\mathrm{O}_{3}$ at selected urban and for-est air quality monitoring stations in Southwest Germany for the period 1992 through 1996.

\begin{tabular}{|l|c|c|c|c|c|c|}
\hline \multirow{2}{*}{} & \multicolumn{2}{|c|}{ NO } & \multicolumn{2}{c|}{ NO $_{2}$} & \multicolumn{2}{c|}{ O$_{3}$} \\
\cline { 2 - 7 } & $\mu \mathrm{g} / \mathrm{m}^{3}$ & $\%$ & $\mu \mathrm{g} / \mathrm{m}^{3}$ & $\%$ & $\mu \mathrm{g} / \mathrm{m}^{3}$ & $\%$ \\
\hline Stuttgart-Mitte & 29.98 & 100.0 & 42.36 & 100.0 & 36.44 & 100.0 \\
\hline $\begin{array}{l}\text { Stuttgart-Bad } \\
\text { Cann-statt }\end{array}$ & 30.23 & 100.8 & 41.79 & 98.7 & 32.31 & 88.7 \\
\hline Welzheimer Wald & 1.44 & 4.8 & 12.87 & 30.4 & 70.30 & 192.9 \\
\hline Freiburg-Mitte & 14.26 & 100.0 & 24.65 & 100.0 & 49.11 & 100.0 \\
\hline Freiburg-Nord & 17.11 & 120.0 & 32.91 & 133.5 & 47.11 & 95.9 \\
\hline Schwarzwald-Süd & 2.15 & 15.1 & 6.46 & 26.2 & 99.62 & 202.9 \\
\hline
\end{tabular}

\section{Conclusions}

In spite of trends in air pollution, it is clear that air quality conditions in close to city forests differ from those within urban agglomeration spaces. Due to the distance to sources of air pollutant emission, the atmosphere within forests is virtually clear of those primary air pollutants which are emitted anthropogeneously. As long as standards for human health are not exceeded, the higher average levels of $\mathrm{O}_{3}$ concentrations within close to city forests may be taken as an in-dication of clean air.

One should not limit the quantification and evaluation of air quality (as it affects humanity) within close to city forests to the regularly monitored air pollutants $\mathrm{NO}, \mathrm{NO}_{2}$ and $\mathrm{O}_{3}$. Other air pollutants with an increasing concern for hu-man health and well-being should also be investigated, such as volatile organic compounds (Mayer and Steil [9]). They can be divided into an- 
thropogenic and biogenic species. Due to the fact, however, that many interesting air pollutants are not continuously recorded, both in close to city forests and the cities themselves, there is unfortunately a lack of time series of such data. In Germany few official stations for the monitoring of air quality are located within forests, due to the philosophy of air pollution control. Most of the stations are within urban and industrial agglomeration areas.

The first step in the right direction has been taken through the applied method in this investigation on the quantification of the air pollution conditions within forests close to cities. The quality of results could be greatly improved if more air pollutants are considered, if consistent data are available from monitoring stations in forests close to cities for different air pollutants over a longer period of time, and lastly if a more extensive statistical analysis is used.

\section{References}

1. Karameris, A., Analyse und Prognose der Erholungsnachfrage in Wäldern als forstlicher Beitrag zur Raumplanung, Forstl. Forschungsber. München, 50, 1982.

2. Mayer, H. \& Höppe, P., Die Bedeutung des Waldes für die Erholung aus der Sicht der Humanbioklimatologie, Forstw. Cbl., 103, pp. 125-131.

3. Matzarakis, A. \& Mayer, H., Mapping of urban air paths for planning in Munich, Wiss. Ber. Inst. Meteor. Klimaforsch. Univ. Karlsruhe, 16, pp. 13-22.

4. Sczepanski, P., Lufthygienische Unterschiede zwischen Stadt und Wald, Diplomarbeit Meteor. Inst. Univ. Freiburg, 1998.

5. Mayer, H., Schmidt, J. \& Matzarakis, A., Lufthygienische Kennzeichen von stadtnahen Wäldern, Wetter und Leben, 46, pp. 49-65, 1994.

6. Mayer, H. \& Haustein, Ch., Air pollution caused by motor-traffic in urban spaces, Meteorol. Zeitschrift, N.F., 3, pp. 138-142, 1994.

7. Haustein, Ch. \& Mayer, H., Investigation on immissions caused by motor-traffic using car traverses, Wiss. Ber. Inst. Meteor. Klimaforsch. Univ. Karls-ruhe, 16, pp. 73-84, 1992.

8. Mayer, H. \& Schmidt, J., Trendanalyse von Immissionszeitreihen in Baden-Württemberg und Bayern, Meteorol. Zeitschrift, N.F., 3, pp. 116$121,1994$.

9. Mayer, H. \& Steil, P., Untersuchungen zur Quantifizierung der Zusammenhänge zwischen Ozonbelastung und Kohlenwasserstoffimmissionen, Bayer. Staatsministerium für Landesentwicklung und Umweltfragen, Reihe Materialien, 139, 1998. 